\title{
YXXP Motif
}

National Cancer Institute

\section{Source}

National Cancer Institute. YXXP Motif. NCI Thesaurus. Code C14059.

YXXP (tyrosine-X-X-Proline), a substrate sequence preferred by Abl tyrosine kinases, is part of the $\mathrm{SH} 2$ domain that mediates certain interactions of $\mathrm{SH} 2$ containing proteins. Although both phosphorylated- and unphosphorylated-YXXP can interacts with $\mathrm{SH} 2$ containing proteins, the $\mathrm{SH} 2$ domain obtain sufficient binding specificity from the recognition of adjacent residues to allow discrimination between different phosphorylated sites. $(\mathrm{NCl})$ 